\title{
Optimization of Marketing Communications of Fisheries, Marine and Food Agriculture of Lhokseumawe City
}

\author{
Kamaruddin Hasan ${ }^{1 *}$, Masriadi Sambo ${ }^{1}$, Riski Amal Muchlis ${ }^{1}$, M. Yahya ${ }^{1}$
}

\author{
${ }^{1}$ Department of Communication Studies, Faculty of Social and Political Sciences, University of Malikussaleh \\ ${ }^{*}$ Corresponding author. Email: kamaruddin@unimal.ac.id
}

\begin{abstract}
The main objective to be achieved in this research is to describe and optimize marketing and business communications in the digital era of marine, fishery and food agriculture products in Lhokseumawe City which side with fishermen and farmers. Describe the potential, symptoms, rules and methods in optimizing marketing and business communications. Using a phenomenological paradigm with a descriptive qualitative approach. Research is designed with case studies to provide a more detailed description of a symptom or phenomenon. The final result of this research is typology, model, strategy or patterns regarding the phenomenon of marketing communication. Primary and secondary data were obtained through observation, interviews and literature review / related documents. Data analysis is done simply by reducing, presenting and concluding. The theoretical basis, concepts and models are used digital marketing communication, promotion, integrated marketing communication, marketing mix models, SWOT analysis, internet and new media inoculation perspective. The results showed the great and good potential of fisheries, marine and food crops in Lhokseumawe City, but the communication and marketing processes were still weak, it needed optimization by synergizing the parties. Still less creative in marketing communications, promotions, online business and online applications by utilizing information communication technology. The conclusion of this research is that in this new era of online marketing, promotion and business of fishery and agri-food commodities, online technology is increasingly advanced and it is easy to reach the public. Internet media has become the main communication medium to obtain information and disseminate information. Fishery and agricultural commodities have various types of products that are of interest or sought by the community. So that we need a medium where fishermen, farmers can sell fishery, agricultural or processed products directly to the community without going through a long and detrimental marketing chain. In addition, it has become a new job site for millennials in particular, in utilizing the internet, especially new media in the process of promotion, marketing and online business. The bargaining position of fishermen and farmers is still weak. Because the market structure tends to be monopsony, oligopoly and even monopoly. In general, fishermen and farmers sell their produce conventionally through intermediary traders with long marketing chains. They do not have direct market access. Because of this, fishermen and farmers feel disadvantaged, they continue to live in poverty and are marginalized.
\end{abstract}

Keywords: Optimization, Digital Marketing Communication, Internet, Fishery Products, Marine and Food Agriculture, Lhokseumawe City

\section{INTRODUCTION}

Lhokseumawe City has a variety of post-oil and gas potentials, in addition to new industrialization as well as potential for production and catch fisheries, aquaculture, marine, and food agriculture. Lhokseumawe City should be a city based on digital trading and marketing businesses including fishery, marine and agricultural products and services.
Fishery, marine and food crop commodities already have a variety of productions and products that are of high demand and are sought after by the community. Even the production and yield potential is high. Even in certain seasons, the production and catch of fish for example by fishpond farmers and fishermen is abundant, especially in certain months with certain types of fish. The types of fish that dominate are tuna, skipjack, anchovies and also various types of kowe fish and flying fish. 
However, it becomes an obstacle when the production and catch is so much, but the market cannot absorb it and the price falls. As a result, production and catches have dropped in price and are unable to provide added value to fishermen.

This is illustrated in the Lhokseumawe Fish Market, when certain fish seasons such as tuna or skipjack, then the price of other fish will also drop. Especially the types of fish that are generally consumed by the domestic market. Meanwhile, the dominant fish consumed by consumers is limited and has export value, the price remains stable.

Even according to data from the Pusong Fish Landing Port Technical Service Unit (UPT), Lhokseumawe, said that from March to early April 2020, the catch of anchovy reached almost 349 tons. Meanwhile, the type of tuna tuna in the same period also reached more than 172 tonnes. This means that the two types of fish are the dominant fish caught by fishermen in Lhokseumawe. However, the abundance of the fishermen's catch does not have a big meaning for the welfare of fishermen. Because the main problem is the inability of the market to absorb, market and it is only limited to local markets with limited purchasing power as well.

Thus, the life of fishermen, including farmers in Lhokseumawe City, is still concerned from all aspects of life. The bargaining position of fishermen and farmers is still weak because the market structure at the fishermen and farmers level tends to be monopsony or oligopoly, or even monopoly.

In general, fishermen and farmers sell fishery, marine and agricultural products conventionally through intermediary traders with long marketing chains. They do not have direct market access and have to go through middlemen, traders, bench shops and others. So that their production and yields will be less value added and less able to support welfare. Even fishermen and farmers feel disadvantaged that they are still living in poverty and marginalized. They, fishermen and traditional farmers are a group of people who can be classified as the poorest, marginalized and underdeveloped social strata among other community groups. Their level of welfare is still below other sectors.

Based on the stratification obtained in the field, fishermen and farmers in Lhokseumawe City are divided into three typologies; first, fishermen and farmers who own ships and agricultural land, so employ fishermen and other farmers without having to work themselves. Second, fishermen and farmers who own boats and paddy fields but still work as boat crews or cultivators. Third, fishermen and farmers whose living needs can be fulfilled with their basic income from working as fishermen and farmers, and owning boats and land without hiring workers from outside their families and the four poor fishermen and farmers, namely fishermen and farmers whose income from boats and land is insufficient. the necessities of life, so that it must be supplemented by other work both for himself and his family.

For that, a comprehensive solution is needed in an effort to improve the livelihoods of fishermen and farmers in Lhokseumawe City. One of the solutions is to increase marketing communication of fishery production and products, marine and food agriculture. This solution is supported by the potential of the city of Lhokseumawe as a city of trade and services, so it is necessary to develop a strategy and synergy of marketing communication with stakeholders. Apart from increasing the quantity and quality of products and services, it is also strengthening in the field of marketing communication, which is an important point in the successful sale of a product and service.

This study is also expected to contribute to the advancement of Communication Science, especially the Communication Research methodology, Marketing / Business communication, Entrepreneurship, Online Business, Online Applications and Communication Technology. That in the marketing, promotion and online business of fishery and agri-food commodities in this new era, online technology has become increasingly advanced and has become easier to reach the general public. Internet media has become the main communication medium to obtain information and disseminate information. The global development of communication and information technology is a worldwide phenomenon that unites people to one another. Globalization results in advances in knowledge and technology. One of them is the internet, which is part of a sophisticated technology, in which there are various kinds of social media.

Based on the background, research problems can be formulated: 1 . How is the utilization of the potential of fisheries, marine and food agriculture in Lhokseumawe City? 2. How is the optimization of marketing communications from fishery, marine and agricultural food products in Lhokseumawe City?

The research objectives are formulated as follows: 1. Describe the potential for marine, fisheries and food agriculture in Lhokseumawe City. 2. Describe and optimize marketing communications and business in the digital era of marine, fishery and food agriculture products from Lhokseumawe City, which sided with fishermen and farmers. 3. Fostering enthusiasm, motivation and entrepreneurial spirit for farmers and fishermen in Lhokseumawe City. 4. Efforts to improve 
the quality of Human Resources in fisheries, marine and food agriculture in Lhokseumawe City.

The benefits of this research, theoretically, are expected to contribute to the implementation of Communication Science, Research methodology, Economics, Marketing / Business communication, Entrepreneurship, Online Business, Online Applications and Communication Technology. Practically, it can be useful for the interests of fishermen and farmers in Lhokseumawe City.

\section{LIBRARY FOUNDATION}

As the basis of the literature, this research process is based on the principles of communication science, especially marketing and business communications, entrepreneurial communication, the potential of fisheries, marine and agricultural food, Lhokseumawe City. Also used the concept of Online Application, Communication Technology, integrated marketing communication (IMC), AIDDA model, 4P7P marketing mix model, Marketing Mix, SWOT analysis and inoculation perspective to dissect literacy skills in using new media for the benefit of marketing fisheries, marine and food agriculture in Lhokseumawe City.

\section{RESEARCH METHODOLOGY}

This study uses a constructivist paradigm with a descriptive qualitative approach. Case study method to provide a more detailed description of a symptom or phenomenon. Data collection techniques are simply carried out by observation, interviews and document or literature study. Analysis and writing techniques, namely Snow ball informants and cross checks of information, synchronization, compaction (process of concise and abbreviating) and conclusions (Conclusion).

\section{RESULTS AND DISCUSSION}

The results showed that, a comprehensive solution is needed in an effort to improve the direction of life of fishermen and farmers in Lhokseumawe City. One solution is to increase the marketing of fishery products, marine and food agriculture. This solution is supported by the potential of the city of Lhokseumawe as a city of trade and services, especially fishery, marine and food agriculture products that need to be developed optimally, including in the marketing strategy. Apart from increasing the quantity and quality of products and services from fishery, marine and agricultural products, it is also strengthening in the marketing sector. Marketing is one of the important points in the success of selling a product and service.

As conveyed by the Secretary of the Ministry of Industry and Trade of Lhokseumawe, Karimuddin
(55), in an interview in November 2020 that, besides having good potential, Lhokseumawe has good potential, but the processing of fishery products is more dominated by types of activities such as salting, drying fish, some wood fish, some fish jerky, the need for fish balls, empek-empek, and this sector, this marine fishery business is still dominant in Banda Sakti sub-district.

However, it is believed that by implementing good marketing communications, including digital, it can increase the added value of fishery, marine and food crop products and products.

Especially the potential of fisheries, marine in Lhokseumawe City is high, even in certain seasons, the fish catch by fishermen is abundant, especially in certain months with certain types of fish as well. The types of fish that dominate the catches of the fishermen of Lhokseumawe are tuna, skipjack, anchovies and also various types of kowe and fly fish.

However, it becomes an obstacle when the catch is so large that the market cannot absorb it and the price falls. As a result, the fishermen's catch has dropped in price and is unable to provide more contributive value to fishermen.

As revealed by a trader at the Lhokseumawe Fish Market named Zakaria (55), in an interview in November 2020, when certain fish seasons such as tuna or skipjack, then the price of other fish also drops. Especially the types of fish that are generally consumed by the domestic market. Meanwhile, the dominant fish consumed by consumers is limited and has export value, the price remains stable.

Even according to data from the Pusong Fish Landing Port Technical Service Unit (UPT), Lhokseumawe, said that from March to early April 2020, the catch of anchovy reached almost 349 tons. Meanwhile, the type of tuna tuna in the same period also reached more than 172 tonnes. This means that the two types of fish are the dominant fish caught by fishermen in Lhokseumawe.

However, the abundance of the fishermen's catch does not have a big meaning for the welfare of fishermen. Because the main problem is the inability of the market to absorb and it is only limited to local markets with limited purchasing power as well. This is a factor in the problem of constraints in fish production. Moreover, fish marketing systems and models are still ongoing and apply traditionally. This means that it is still being carried out between traditional markets on a regional basis in several regions in Aceh Province.

For tuna fish and the like, it becomes a problem in itself if the catch is large. However, it is different from anchovies. Even when the catch is 
abundant, the market's absorption capacity can still accommodate these types of fish to be processed into other products. Namely processed into dried anchovies or in the local language it is called "Kareeng". Meanwhile, tuna, can only be processed into wooden fish or what is known in the Aceh language "Keumamah". Glancing at marketing types of dried anchovies have made little progress. Where teri tering originating from Lhokseumawe city has good quality and is in demand by the market. Both local markets in Aceh and markets in other cities on the island of Sumatra.

Teri Kering, which are processed products of anchovy, are found around Lhokseumawe-North Aceh waters (Malacca Strait). Even in certain months the catch is abundant. Teri catching mostly occurs around February to May, while the catch reaches its peak in April. Meanwhile, in other months, the results were not as big as in April.

From data from the Disperindagkop of Lhokseumawe City, there are 20 fishery product processing business units in Lhokseumawe City. Where in general, the type of fish processing is a business of salting and drying fish into salted fish commodities and the like. While other processed products are fish balls, empek-empek and wooden fish. Meanwhile, the marketing model as mentioned above is still very dominant in a conventional manner from the market to the market through the services of Mugee (mobile traders on motorbikes) and also supplied in large quantities to a number of traditional markets in other areas.

Meanwhile, the use of information technology by using certain applications in marketing fishery products is still very minimal. Even though there are those who use information media services, it is still limited to the type of social media and there is no specific marketing application in marketing these fishery products. Of several fishery production business actors in Lhokseumawe City, there are also marketing their fishery production through social media. Like Facebook, Whatshapp and also Instagram. However, the number of each is very small.

Regarding the types of fishery product commodities that are marketed through social media networks, this is the type of processed fish production. Among several variants of processed fishery products, among others, fish balls, stir-fried shrimp, sauteed wood fish and crispy anchovies. As for the types of raw fishery products, no one has marketed them using digital information and is still limited to conventional types of marketing.
A young entrepreneur engaged in various agricultural product sectors, Azhari Vinca Rosea, regarding the potential of fishery products in Lhokseumawe City said that the potential of various types of fish for export commodities is very enlightening in Lhokseumawe City. because many types of fish caught by fishermen in Lhokseumawe City have export value. In addition, the catch fish, several types of cultivated fish carried out by keramba farmers in LHokseumawe also have export value.

That is, several types of fish that have export value at this time include grouper, tuna, skipjack, goat fish, ranjungan crab and several other types of reef fish. The various types of fish referred to, most of which are the catch of fishermen and specifically for groupers, are the results of the cultivation of keramba farmers along the Krueng Cunda River.

Geographically, Lhokseumawe City consists mostly of coastlines and is supported by favorable regional conditions from various products from the fishery sector. So that it is appropriate with the intended potential, it can be worked to the maximum as an effort to increase and will provide added value to people's income.

After all, all products and services still boil down to marketing. It is hoped that marketing will become a top priority regarding how good marketing tips and most importantly, marketing tools also play a role. Effective marketing tools are quick, precise and clear. The current era of digital technology, the presence of digital information-based facilities is no longer a new thing in the business world but has become an important part of business transactions because with the ease with which most people have used gadgets that are connected to various access to information and other needs.

One solution is to increase the marketing of fishery products, marine and food agriculture. This solution must be supported by the potential of the city of Lhokseumawe as a city of trade and services, especially fishery, marine and food agriculture products that need to be developed optimally, including in the marketing strategy. Apart from increasing the quantity and quality of products and services from fishery, marine and agricultural products, it is also strengthening in the marketing sector. Marketing is one of the important points in the success of selling a product and service.

So here it can be understood, that the presence of digital-based information technology is an important part of the marketing of various business products, because it will reach consumers faster and also be efficient in terms of costs, time and so on when compared to conventional marketing methods. 


\section{CONCLUSIONS AND SUGGESTIONS}

Marketing and online business of fishery, marine and agricultural products through social media need to be encouraged. Social media itself is a means of online social communication in cyberspace. This social media has a big influence on society. The internet helps its users to obtain information and interact with other users through social media. Social media is a site where users can interact with other users. Social media is also a place to share user activities or activities. Users are also not complicated in making social media and there are no limits on space and time.

Internet media has become the main communication medium to obtain information and disseminate information. Fishery and agricultural commodities have various types of products that are of interest or sought by the community. So that we need a medium where fishermen, farmers can sell fishery, agricultural or processed products directly to the community without going through a long and detrimental marketing chain. In addition, it has become a new job site for millennials in particular, in utilizing the internet, especially new media and / or social media in the process of promoting, marketing and online business of fishery, marine and agricultural food products / services in Lhokseumawe City.

\section{REFERENCES}

Branan, Tom. 1998. Komunikasi Pemasaran. Jakata: PT Gramedia Pustaka Utama

Burhan, Bungin. (2005). Metodologi Penelitian Kuantitatif Komunikasi, Ekonomi, dan Kebijakan Publik Serta Ilmu-Ilmu Sosial Lainnya, Edisi Pertama. Jakarta, Prenada Media.

Diaz Praditya. (2019). Prediksi Perkembangan Industri E-commerce Indonesia pada Tahun 2022.Techinasia. Diakses 25 Agustus 2019.

Donny B.U. (ed.). (2018). Kerangka Literasi Digital. Jakarta: Siberkreasi - FIRAL - ICT Watch Relawan TIK - Internet Sehat.

Dewi Sad Tanti' Adharis Kuswidiarto, Prosiding: SEMINAR NASIONAL PENINGKATAN MUTU PERGURUAN TINGGI Universitas Mercu Buana Jakarta Tanjung Benoa-Bali, 29 Nopember 2019. Memetakan Kompetensi Digital Petani Pengguna Platform Promosi dan Pemasaran Digital Agribisnis. Mapping Digital Farmers' Competency as Digital Agribusiness, Promotion and Marketing Platform Users, Program Studi Ilmu Komunikasi, Universitas Mercu Buana, Jakarta
Eka Randy. (2016). Daftar Startup Indonesia di Bidang Pertanian, Perikanan, dan Peternakan DailySocial.id dilihat 25 Agustus 2019.

Heriyanto. (2017). "Kompetensi Digital sebagai Strategi Peningkatan Pendidikan Tinggi di Era Modern (Studi Deskriptif pada Sekolah Tinggi Agama Buddha Negeri Sriwijaya Tangerang Banten)". Seminar Lokal Sekolah Tinggi Agama Buddha Negeri Sriwijaya. Tangerang Banten. Kementerian Komunikasi dan Informatika. (2018). "Kementerian Kominfo Sebut Pengguna Internet Indonesia Capai 54 Persen". Dirujuk pada 25 Agustus 2019.

Mulyana, Deddy. (2001). Metode Penelitian Kualitatif lmu Komunikasi. Cetakan pertama.Bandung: Remaja Rosdakarya.

Branan, Tom. 1998. Komunikasi Pemasaran. Jakata: PT Gramedia Pustaka Utama

Burhan, Bungin. (2005). Metodologi Penelitian Kuantitatif Komunikasi, Ekonomi, dan Kebijakan Publik Serta Ilmu-Ilmu Sosial Lainnya, Edisi Pertama. Jakarta, Prenada Media.

Diaz Praditya. (2019). Prediksi Perkembangan Industri E-commerce Indonesia pada Tahun 2022.Techinasia. Diakses 25 Agustus 2019.

Donny B.U. (ed.). (2018). Kerangka Literasi Digital. Jakarta: Siberkreasi - FIRAL - ICT Watch Relawan TIK - Internet Sehat.

Dewi Sad Tanti' Adharis Kuswidiarto, Prosiding: SEMINAR NASIONAL PENINGKATAN MUTU PERGURUAN TINGGI Universitas Mercu Buana Jakarta Tanjung Benoa-Bali, 29 Nopember 2019. Memetakan Kompetensi Digital Petani Pengguna Platform Promosi dan Pemasaran Digital Agribisnis. Mapping Digital Farmers' Competency as Digital Agribusiness, Promotion and Marketing Platform Users, Program Studi Ilmu Komunikasi, Universitas Mercu Buana, Jakarta

Eka Randy. (2016). Daftar Startup Indonesia di Bidang Pertanian, Perikanan, dan Peternakan. DailySocial.id dilihat 25 Agustus 2019.

Heriyanto. (2017). "Kompetensi Digital sebagai Strategi Peningkatan Pendidikan Tinggi di Era Modern (Studi Deskriptif pada Sekolah Tinggi Agama Buddha Negeri Sriwijaya Tangerang Banten)". Seminar Lokal Sekolah Tinggi Agama Buddha Negeri Sriwijaya. Tangerang Banten. Kementerian Komunikasi dan Informatika. (2018). "Kementerian Kominfo Sebut Pengguna Internet Indonesia Capai 54 Persen". Dirujuk pada 25 Agustus 2019.

John, Kenedy dan Dermawan, Seomangere. 2006. Marketing Communication Teknik Dan Strategi. Jakarta. Bhuan Ilmu Populer. 
Kementerian Pertanian RI. (2015). Rencana Strategis Kementerian Pertanian Tahun 2015-2019. Jakarta: Biro Perencanaan, Sekretariat Jenderal.

Kotler dan Keller. (2012). Manajemen Pemasaran. Edisi 12. Jakarta: Erlangga

Kotler P. G Armtrong. Philip. 2001. Manajemen Pemasaran: Analisis Perencanaan, Implemantasi dan Kontrol.PT. Prehal Indo. Jakarta.

Kamsiah, Tasrudddin. 2011. Strategi Pemasaran Dalam Perspektif Komunikasi Pemsaran. Alauddin Universiti.

Koentjaraningrat dan Donald K. Emerson (ed), 1982. Aspek Manusia dalam Penelitian Masyarakat, Jakarta: PT. Gramedia.

Lhokseumawe dalam Angka 2020, BPS

Prisgunanto, Ilham. 2006. Komunikasi Pemasaran Strategi dan Taktik. Bogor. Gralita Indonesia.

Prayoga, Kadhung. (2017). "Aplikasi Digital Pertanian: Geliat Pemberdayaan Petani di Era Virtual" Diakses dari academia.edu.

Mulyana, Deddy. (2001). Metode Penelitian Kualitatif Imu Komunikasi. Cetakan pertama.Bandung: Remaja Rosdakarya.

Nurbenny. 2005. Manajemen Pemasaran Modern. Jogjakarta. Liberty.

Nielsen. (2017). Penetrasi Media Survei Nielsen Indonesia 2017. Jakarta: The Nielsen Company. Permadi, Dedy dan Viyasa Rahyaputra. (2018). Strategi Kewirausahaan Digital: Sebuah Panduan untuk UMKM, Stratup dan ECommerce. Seri Literasi Digital. Jakarta: Kominfo -CfDS - Siberkreasi.

McQuail, Denis, 2005, McQuail's Mass Communication Theory, London, Sage Publications

https://kominfo.go.id/content/detail/15380/kementeriankominfo-sebut-pengguna-internet- indonesia-capai-54persen. 